University of Nebraska - Lincoln

DigitalCommons@University of Nebraska - Lincoln

2001

\title{
Combining Activity-Based Costing with the Simulation of a Cellular Manufacturing System
}

\author{
Paul Savory \\ University of Nebraska at Lincoln, psavory2@gmail.com \\ Robert Williams \\ University of Nebraska at Lincoln \\ Rodney Rassmuseun \\ University of Nebraska at Lincoln
}

Follow this and additional works at: https://digitalcommons.unl.edu/imsefacpub

Part of the Industrial Engineering Commons, Operational Research Commons, and the Other Operations Research, Systems Engineering and Industrial Engineering Commons

Savory, Paul; Williams, Robert; and Rassmuseun, Rodney, "Combining Activity-Based Costing with the Simulation of a Cellular Manufacturing System" (2001). Industrial and Management Systems Engineering Faculty Publications. 61.

https://digitalcommons.unl.edu/imsefacpub/61

This Article is brought to you for free and open access by the Industrial and Management Systems Engineering at DigitalCommons@University of Nebraska - Lincoln. It has been accepted for inclusion in Industrial and Management Systems Engineering Faculty Publications by an authorized administrator of DigitalCommons@University of Nebraska - Lincoln. 


\title{
Combining Activity-Based Costing with the Simulation of a Cellular Manufacturing System
}

\author{
Paul A. Savory \\ Robert E. Williams \\ Rodney R. Rasmussen \\ Industrial and Management Systems Engineering \\ University of Nebraska - Lincoln \\ Lincoln, NE 68588-0518 \\ e-mail: psavory@unl.edu
}

\begin{abstract}
Discrete-event simulation is one of the most effective techniques for analyzing a manufacturing system. Unfortunately, little attention is given to using simulation models to estimate the economic impact of a proposed system configuration. This paper defines how activity-based costing (ABC) concepts can be incorporated into a discrete-event simulation model. Special emphasis is on demonstrating how decision making can be aided by having the simulation create a detailed "Bill of Activity" describing costs associated with manufacturing a part. The integration of $\mathrm{ABC}$ and simulation is illustrated by evaluating the impact of a proposed manufacturing cell configuration. The additional costing information aids in cell design, determining part sequencing and scheduling, and provides a quick evaluation of product mix changes for a part family.
\end{abstract}

Keywords: simulation, activity-based accounting, cost estimation 


\section{INTRODUCTION}

Simulation uses range from comparing alternative system designs to answering capacity and feasibility questions. It is one of the most important operations research techniques for analyzing manufacturing systems [1]. Unfortunately, traditional approaches to simulation analysis focus primarily on evaluating the results of system performance variables (e.g., resource utilization, inventory levels, cycle time, throughput time) under varying conditions. A cost/benefit analysis has typically been accomplished only through separate efforts. Since business decisions are based on cost and profitability, it is only natural that simulation studies should also include cost considerations.

There are three general approaches for incorporating cost estimation with simulation. Christy and Kleindorfer [2] provide an extensive review of the research and literature describing each. The first approach directly incorporates costing extensions into a simulation language or package. One such simulation package is SIMPROCESS produced by CACI. With SIMPROCESS, a user defines cost periods for cost calculation purposes, sets up resource costs and then runs the simulation model. SIMPROCESS automatically tracks all the activities that use the resources and all the types of entities processed in those activities. The key problem with this costing approach is that few languages/packages include costing provisions and when they do, they rarely represent accepted accounting practice [3]. The second approach, the most common, develops costing estimates off-line during a post-processing step that uses the final results generated from the simulation. Krishnamurthi et al. (1994) applies this estimation technique to an existing simulation model. The third method incorporates costing analysis routines directly into the simulation model. As such, it collects data on-line as part of the 
execution of the simulation model. Christy and Kleindorfer [2] and McLanahan and Ketcham [3] demonstrate this approach for simple manufacturing models.

If production costs are among the required decision parameters sought by running a simulation model, procedures for obtaining on-line costing should be added to the model during its development. Krishnamurthi et. al. [4] would disagree by asserting that on-line costing will negatively impact model run time and complexity. While this is true, it is generally acknowledged that complexity and run time are driven by model fidelity and decision parameter data requirements. As such, all decision parameters, including cost metrics, integral to the decision making process should be included in the simulation model development. Krishnamurthi et. al. [4] also states that a disadvantage of the on-line approach is that the simulation must be re-run if cost information changes. This is not necessarily true. It is likely that small cost change estimates may be obtainable using simple proportional adjustments.

One technique for having a simulation produce cost estimates is to incorporate activitybased costing (ABC) concepts as part of the simulation model. Krishnamurthi et. al. [4] have explored $\mathrm{ABC}$ and simulation by implementing a Turbo $\mathrm{C}++$ module to interface off-line with manufacturing simulation models. Their approach is limited and only yields the base production cost for a part. Our approach is more explicit and seeks to directly assign costs to sources (e.g., direct labor, indirect labor, and overhead costs) using an on-line collection method. At the end of a simulation, a detailed "Bill of Activity" is produced describing all the costs associated with manufacturing a part. The costing information is quite extensive and has the potential to benefit cell design, part sequencing and scheduling, and determining the economic impact of changing product mix within a part family. 
P. Savory, R.E. Williams, and R. Rasmussen (2001), "Combining Activity-Based Costing with the Simulation of a Cellular Manufacturing System,” Journal of Design and Manufacturing Automation. Volume 1, No. 3, pp. 221-

229.

The remaining sections of the paper demonstrate how simulation and $A B C$ techniques can be combined for improving decision-making. Section 2 provides an overview of activitybased cost accounting. Section 3 describes a cellular manufacturing system and presents an ABC representation. Section 4 discusses collecting ABC cost estimates using a SIMAN simulation model. Section 5 explains the Bill of Activity produced by the simulation model. Section 6 presents an overview of the research.

\section{ACTIVITY-BASED COST ACCOUNTING}

Since traditional accounting methods do not accurately measure product allocated costs, product cost accounting is one of the more difficult tasks in modern manufacturing [5]. As a solution, Kaplan [6] proposes that rather than allocate product costs broadly across cost categories, one should use a dynamic system of cost allocation. One such technique is ActivityBased Cost Accounting, also referred to as Activity-Based Costing (ABC), which directly attributes cost to the value of the activities involved in producing a part.

The foundation of $\mathrm{ABC}$ is the realization that products require companies to perform activities (work generating processes or procedures). In turn, performing activities results in associated costs. These costs are grouped into two groups, those that are associated with a product flow and those that are not. Costs that are traceable to product flow are ultimately assigned to a product. Non-product flow costs are assigned to the activities that make the costs necessary [7]. As an example, raw materials consumed during part production would be directly traceable to the product flow. In comparison, utility (e.g., electricity, natural gas) costs would be associated with the various activities that require those resources. These latter costs would be passed on to products based on their activity use. 
P. Savory, R.E. Williams, and R. Rasmussen (2001), "Combining Activity-Based Costing with the Simulation of a Cellular Manufacturing System,” Journal of Design and Manufacturing Automation. Volume 1, No. 3, pp. 221-

229.

Since activities require resources to be consumed and products require activities to be performed, an $\mathrm{ABC}$ implementation is designed as a two-stage process [8]. The first stage transfers costs associated with resource consumption and support to activities, while the second stage allocates the activity costs to the parts. These are referred to as the first-stage cost drivers (or resource drivers) and second-stage cost drivers (or activity drivers). Figure 1 presents a simplified ABC structure. In general, resource consumption and support costs are passed to activity centers and activity centers pass costs on to products based on use.

\section{$<<<$ Figure 1 Approximately Here $>>>$}

One of the key concepts in $\mathrm{ABC}$ is defining activity centers. An activity center is a collection of activities that a manager would like to effectively control. Specifically, activity centers are homogeneous processes such as a manufacturing cell, machining or assembly functions, or a business process such as procurement or marketing. With $\mathrm{ABC}$, the costs associated with resource consumption are first grouped into one of the cost pools at each activity center. Cost pooling gives managers the data necessary for planning and controlling activities, and for measuring activity center performance [9].

While it is true that costs are directly allocated to products using activity drivers, there is however, an important consideration that is not so obvious. Costs can be incurred at different levels. That is, some costs are incurred by unit (or part), some by batches, and other costs are by product line. Figure 2 illustrates how cost allocation is accomplished using a hierarchy. For example, parts flowing through a machining process can incur costs at the unit level if the operations on a part are independent from those on preceding or subsequent parts. The costs associated with setting up a machining center most likely will be for a batch of similar parts. The setup cost would be allocated to the batch instead of each individual part. Batch costs would 
P. Savory, R.E. Williams, and R. Rasmussen (2001), "Combining Activity-Based Costing with the Simulation of a Cellular Manufacturing System,” Journal of Design and Manufacturing Automation. Volume 1, No. 3, pp. 221229.

flow to the unit level based on the average setup cost per unit. Tooling costs associated with a new product would be allocated at the product level. In turn, the product costs would flow to the unit level via an average unit cost based on an estimated number of products to be produced over the tooling cost amortization period.

\section{$<<<$ Figure 2 Approximately Here $>>>$}

$\mathrm{ABC}$ is not without disadvantages. If it is not implemented correctly, ABC can inundate managers with too much detail. Dhavale [5] remarks that, "ABC in its most detailed form is thus not suitable for practical applications because it fails to provide usable information to a manager." Therefore, any costing implementation must be based on the requirements of the people it will serve and provide sufficient detail necessary to address each user's needs. The objective is to allow better decisions to be made due to the more accurate measure of the costs associated with an organization's products and activities.

\section{DESCRIPTION OF A MANUFACTURING CELL}

To illustrate developing costing estimates with a simulation model, consider a cellular manufacturing system that processes a single part family. The cell is comprised of four machines: two identical computer numerically controlled (CNC) lathes, one CNC machining center, and one universal grinder. There are two operators within the cell. The first operator is responsible for all material handling, setup, loading/unloading, processing, and quality control inspection for the two lathes. The second operator has the same job responsibilities but is associated with the machining center and the universal grinder. The cell layout is shown in Figure 3.

\section{$<<<$ Figure 3 Approximately Here $>>>$}


The part family processed by the cell consists of four parts types (A, B, C, and D). Parts arrive to the cell in homogeneous batches of a specific part type. The batch size and processing sequence for each part type is shown in Table 1. Batches arrive following an exponential distribution with a mean of four hours and forty minutes. Part type is based on production mix requirements and has the following breakdown: 30\% Type A, 20\% Type B, 40\% Type C, and $10 \%$ Type D.

\section{$<<<$ Table 1 Approximately Here $>>>$}

For each batch, the setup time is dependent on whether the previous batch was of the same part type or not. Table 2 shows the distributions used for the long and short setup times at each machine. After the batch setup is complete, an individual part is selected, moved to the machine, loaded, processed, unloaded, moved to the inspection station, and inspected. This cycle is performed at each machine until all parts within the batch are complete. The following distributions representing part loading, unloading, and inspection times are common to all four machines:

- Part Loading Time: normally distributed with a mean of 3 minutes and a standard deviation of .5 minutes.

- Part Unloading Time: normally distributed with a mean of 2 minutes and a standard deviation of .25 minutes.

- Part Inspection Time: uniformly distributed between 1.5 and 2 minutes.

Part processing time distributions for each part type are given in Table 3. The rejection rate per inspection is $2 \%$. Material handling or move times are based on the distances between the various machines and the time for the respective operator to travel from one point to another.

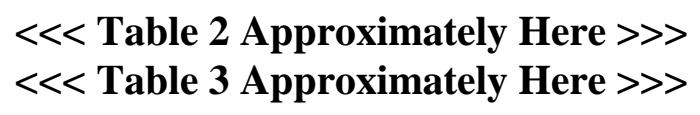


Both preventive and repair (corrective action) maintenance is considered within the cell. The time between machine failures is based on an increasing failure rate Weibull distribution with a mean of 90 days. If no repair actions occur, preventive maintenance is performed on a 30day schedule. If a repair action occurs, a partial preventive maintenance effort is accomplished if within 15 days of the last action, otherwise a full preventive maintenance effort is completed. Probability distributions for describing the required maintenance times are divided into: repair action (triangularly distributed with a minimum of 20, a maximum of 120, and a mode of 60 minutes), full preventative maintenance action (uniformly distributed with a minimum of 50 and a maximum of 70), and partial preventative maintenance action (uniformly distributed with a minimum of 25 and a maximum of 35).

The cell operates for two consecutive eight-hour shifts over a six-day workweek. Parts in process at the end of a second shift are completed before shutting down for the day. Production scheduling is based on completing at least 1080 Type A, 720 Type B, 1440 Type C, and 360 Type D parts within 51 weeks of annual operation.

An activity-based costing depiction of the cellular manufacturing system is presented in Figure 4. Since this is a proposed system, there is a lack of specific information concerning the facility, the business, product development, and other manufacturing aspects. As a result, areas in Figure 4 highlighted by a dotted box were not addressed as part of our costing effort. 


\section{DEVELOPMENT OF THE SIMULATION MODEL}

A simulation model of the manufacturing cell was developed in the SIMAN simulation language [10]. The procedure for recording cost information primarily uses a set of attributes associated with each part (entity). These attributes record part type, batch setup time, part loading time, processing time, unloading time, and part movement time. In general, as each entity passes though the manufacturing process, the time associated with each action performed on the entity is recorded in an attribute. When all processing is complete on a part, the information is accumulated in a set of SIMAN variables by part type and machine in order to establish costs. All data collection and cost estimation is performed using the constructs of the SIMAN simulation language. There is no user-written inserts or code linked into the simulation model. To achieve this, SIMAN blocks/variables such as MREP, NREP, WRITE, READ, and WHILE were used. The only SIMAN summary statistics used by the cost accounting procedure are related to preventive and repair maintenance actions. In these instances, frequency times and totals were used to establish the total time for each type of maintenance action.

Each replication of the model simulates 51 weeks of the manufacturing cell's operations.

At the end of each replication, the model writes the accumulated costing information collected (and stored in SIMAN variables) during the simulation run to a data file. After the thirtieth and final replication, all the information from the data file is read back into the simulation model and processed to calculate average values for the thirty replications. The resulting averages are used by the model to generate the Bill of Activity and Detailed Bills of Activity described in the next section. 


\section{BILLS OF ACTIVITY}

The objective of implementing $\mathrm{ABC}$ is to obtain the cost contribution associated with activities resulting from the design and manufacturing of products. The Bill of Activity and associated Detailed Bills of Activity provide this breakdown. For each part type in the simulated production process, the simulation model produces a Bill of Activity that defines the total cost and per unit cost associated with each activity center [8]. Figure 5 contains the Bill of Activity generated by simulation model for describing the production of the type A parts in the cellular manufacturing system. Notice that there are two general categories of activity centers: Manufacturing and Product Development. Manufacturing costs are associated with all activities that incur cost as the result of making the product. For instance, the manufacturing cost per unit of part type A is estimated to be $\$ 266.68$. This cost is simply the sum of the activity center costs that flow down to the part during the manufacturing process. Product development costs include product design, part coding, and initial tooling costs. This information is not included in this analysis. In general, cost per unit for each category would normally be provided.

\section{$<<<$ Figure 5 Approximately Here $>>>$}

The Detailed Bills of Activity breaks each activity center's cost into specific cost pools. Figure 6 provides a subset of these costs in the production of the type A parts. Note that the cost for the Quality Control activity center is divided into two cost pools: Indirect Labor Hours and \# of Inspections. The simulation model keeps track of the quantity, rate, total cost, and cost per unit for each pool. Using this information, an activity center's cost is the sum of the costs associated with each of its cost pools relative to each pool's respective cost driver. In general, the per unit cost established at the cost pool is a rate. This rate multiplied by the associated cost driver quantity yields the respective total cost for the cost driver. When this total cost is divided 
P. Savory, R.E. Williams, and R. Rasmussen (2001), "Combining Activity-Based Costing with the Simulation of a Cellular Manufacturing System,” Journal of Design and Manufacturing Automation. Volume 1, No. 3, pp. 221229.

by the number of units produced, the cost per unit associated with the cost driver is determined.

Note that the detailed information for the CNC Lathe \#1 activity center is similar, but is further expanded to account for its cost pools.

\section{$<<<$ Figure 6 Approximately Here $>>>$}

\section{CONCLUSIONS}

For an analysis technique to be useful, the output it produces must be understandable to all levels of an organization. Even though the cost of a system/part is a universal performance characteristic, few have explored using a simulation model to generate costing estimates. Simulation models traditionally help in the estimation of production metrics such as machine utilization and waiting times. However, to get a better insight in the impact of proposed changes in a manufacturing system, it is necessary to know its cost implication [4]. This paper is an initial effort in combining activity-based costing with simulation. Specifically, the paper:

(1) reviews how cost estimation and simulation can be combined,

(2) integrates activity-based costing concepts into the simulation model of a cellular manufacturing system,

(3) produces a detailed bill of activity describing costs associated with producing a part.

The integration of ABC with a discrete-event simulation model produces a detailed cost analysis. The added costing information provides an economic assessment of the system being evaluated and allows better decisions at all level of an organization to be made [11]. In addition, costing information can be used to price parts, identify costly production tasks, aid in cell design, determine the impact of part sequencing and scheduling decisions, and provides a quick evaluation of product mix changes for a part family. 


\section{ACKNOWLEDGMENTS}

The authors gratefully acknowledge the support of the Center for NonTraditional Manufacturing and the Nebraska Research Initiative.

\section{REFERENCES}

1. Lane, M.S., Mansour, A.H. and Harper, J.L., Operations Research Techniques: A Longitudinal Update 1973-1988, Interfaces. Vol. 23, No. 2, pp. 63-68, 1993.

2. Christy, D.P. and Kleindorfer, G.B., Simultaneous Cost and Production Analysis of Manufacturing Systems, Proceedings of the 1990 Winter Simulation Conference, ed. Balci, O., Sadowski, R.P., and Nance, R.E., New Orleans, Louisiana, pp. 582-589, 1990.

3. McLanahan, C. and Ketcham, MG., The Representation of Accounting Data in Industrial Simulation" Proceedings of the 1990 Winter Simulation Conference, ed. Balci, O., Sadowski, R.P., and Nance, R.E., New Orleans, Louisiana, pp. 570-577, 1990.

4. Krishnamurthi, M., Jayashankar, R., and Phillips, D.T., An Activity Based Costing Interface to Manufacturing Simulation, Transactions of North American Manufacturing Research Institute of the Society of Manufacturing Engineers, Vol. XXII , pp. 357-363, 1990.

5. Dhavale, D., Activity-Based Costing In Cellular Manufacturing Systems, Industrial Engineering, Vol. 24, No. 2, pp. 44-46, 1992.

6. Kaplan, R.S., Management Accounting for Advanced Technological Environments,” Science, pp. 59-67, August 25, 1989.

7. Hicks, D.T., Activity-Based Costing for Small and Mid-Sized Businesses: An Implementation Guide, John Wiley \& Sons, New York, 1992.

8. O'Guin, M.C., The Complete Guide To Activity-Based Costing, Prentice Hall, Englewood Cliffs, New Jersey, 1991.

9. Dhavale, D., Activity-Based Costing In Cellular Manufacturing Systems, Cost Management, Vol. 7, No. 1, 13-27, 1993.

10. Pegden, C.D., Shannon, R.E., and Sadowski, R.P., Introduction to Simulation Using SIMAN McGraw Hill, New York, 1990.

11. O'Loughlin, M.J., Driskell, M.K., and Diehl, G., Financial Simulation: Combining Cost Information In Systems Analysis, Proceedings of the 1990 Winter Simulation Conference, ed. Balci, O., Sadowski, R.P., and Nance, R.E., New Orleans, Louisiana, pp. 578-581, 1990. 
Table 1. Batch size and processing sequence for each of the four part types.

\begin{tabular}{|c|c|c|c|c|c|}
\hline Part Type & Batch Size & CNC Lathe \#1 & CNC Lathe \#2 & CNC Machining & Universal Grinder \\
\hline A & 4 & 1 & 2 & 3 & 4 \\
\hline B & 3 & 1 & 2 & N/A & 3 \\
\hline C & 6 & 1 & 2 & 3 & N/A \\
\hline D & 2 & 1 & 2 & N/A & N/A \\
\hline
\end{tabular}

Table 2. Probability distributions describing the setup items for each machine. Short set-up occurs if the previous batch was the same part type, otherwise Long set-up occurs.

\begin{tabular}{|c|c|c|c|c|}
\hline Setup & CNC Lathe \#1 & CNC Lathe \#2 & CNC Machining & Universal Grinder \\
\hline Short & Triangular $(30,60,90) / 4$ & Triangular $(30,60,90) / 4$ & Triangular $(30,45,60) / 4$ & Triangular $(20,40,60) / 4$ \\
\hline Long & Triangular $(30,60,90)$ & Triangular $(30,60,90)$ & Triangular $(30,45,60)$ & Triangular $(20,40,60)$ \\
\hline
\end{tabular}

Table 3. Part processing distributions for each part type and each machine.

\begin{tabular}{|c|c|c|c|c|}
\hline $\begin{array}{c}\text { Part } \\
\text { Type }\end{array}$ & $\begin{array}{c}\text { CNC } \\
\text { Lathe \#1 }\end{array}$ & $\begin{array}{c}\text { CNC } \\
\text { Lathe \#2 }\end{array}$ & $\begin{array}{c}\text { CNC } \\
\text { Machining }\end{array}$ & $\begin{array}{c}\text { Universal } \\
\text { Grinder }\end{array}$ \\
\hline A & Triangular $(10,15,20)$ & Triangular $(10,15,20)$ & Triangular $(10,20,30)$ & Triangular (10, 20, 30) \\
\hline B & Triangular $(10,15,20)$ & Triangular $(10,15,20)$ & N/A & Triangular (10, 20, 30) \\
\hline C & Triangular $(10,15,20)$ & Triangular $(10,15,20)$ & Triangular (10, 15, 20) & N/A \\
\hline D & Triangular $(10,15,20)$ & Triangular $(10,15,20)$ & N/A & N/A \\
\hline
\end{tabular}




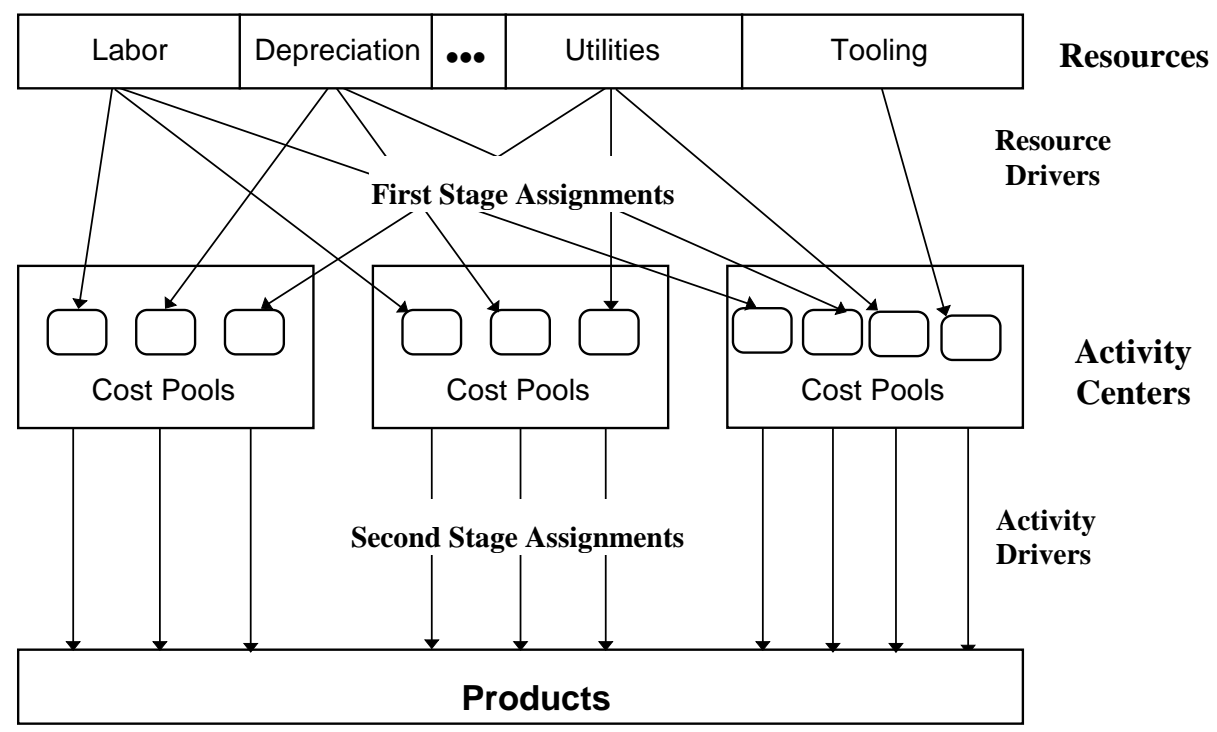

Figure 1. Simplified ABC structure 


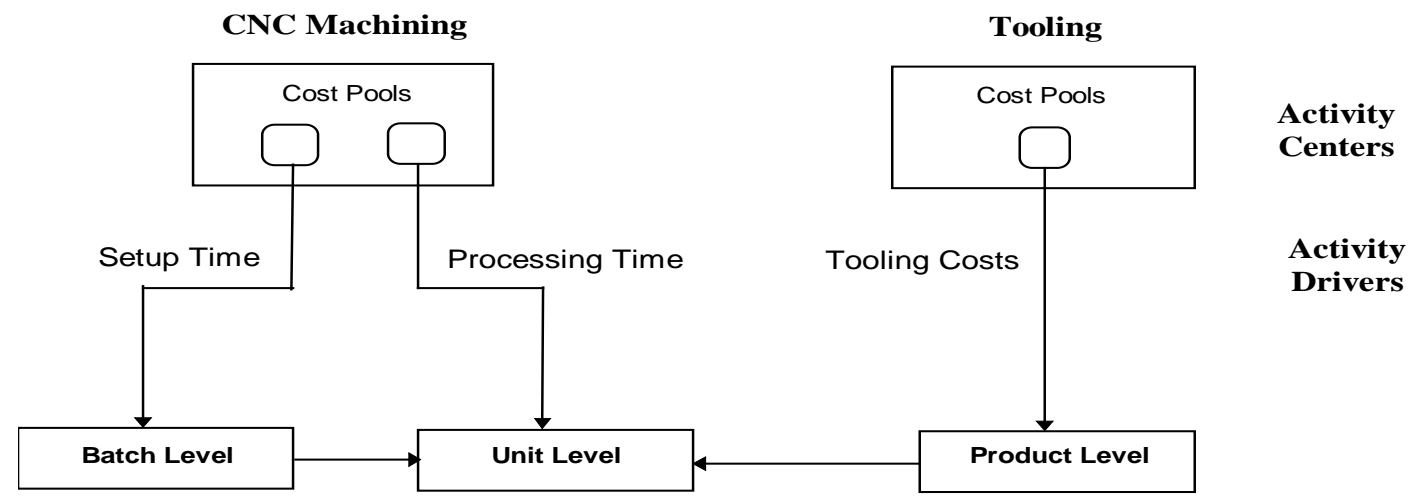

Figure 2. Example of a simple cost allocation hierarchy 


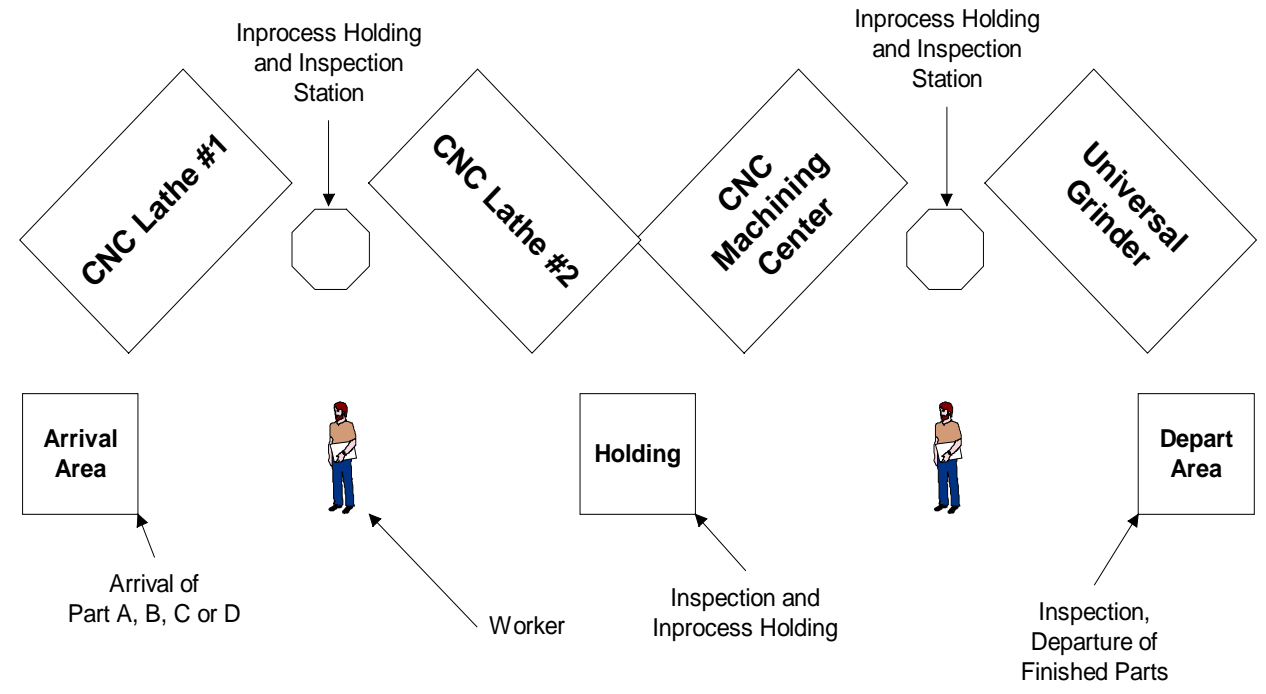

Figure 3. Description of the manufacturing cell. 


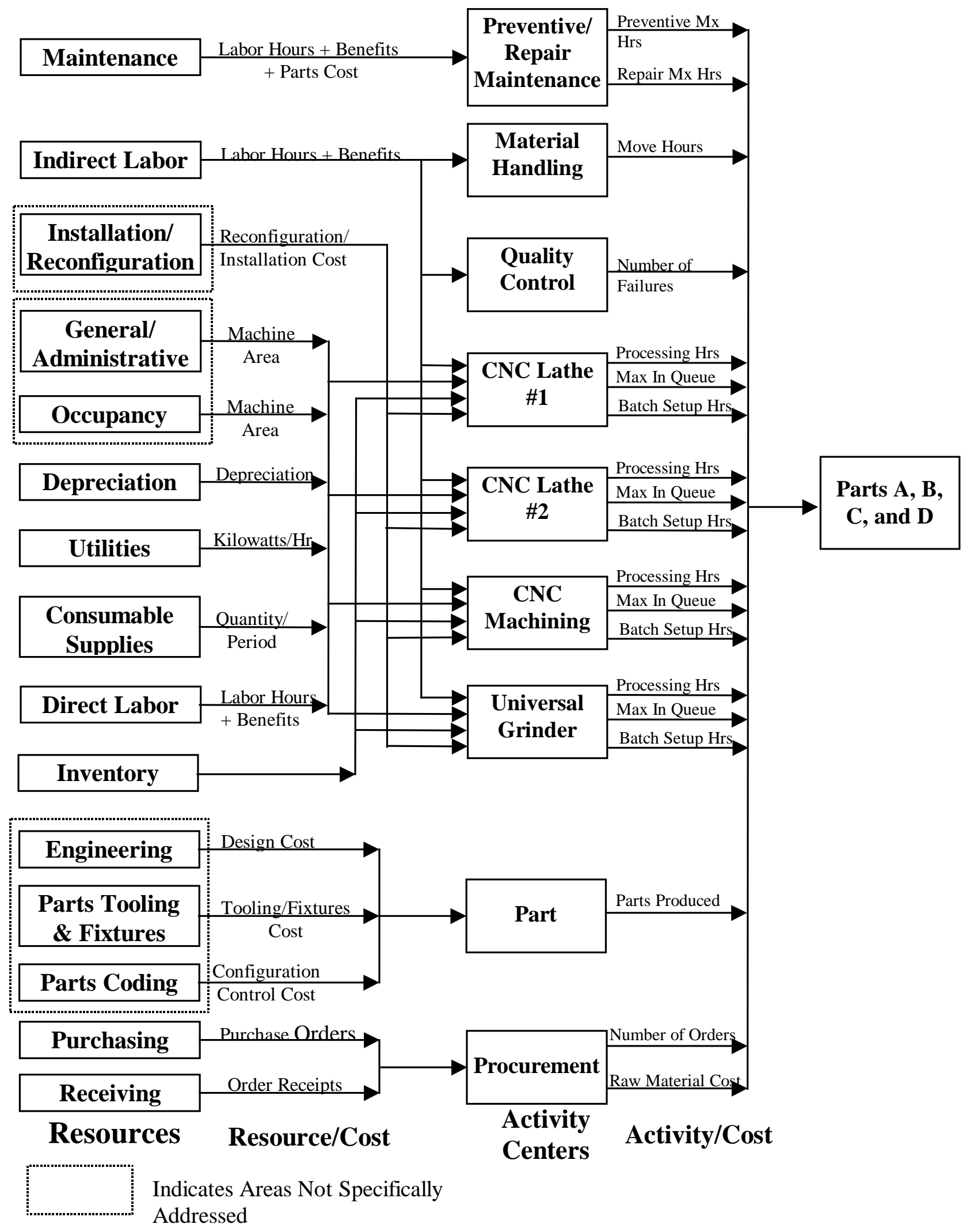

Figure 4. ABC representation of the manufacturing cell cost components. 
Bill of Activity

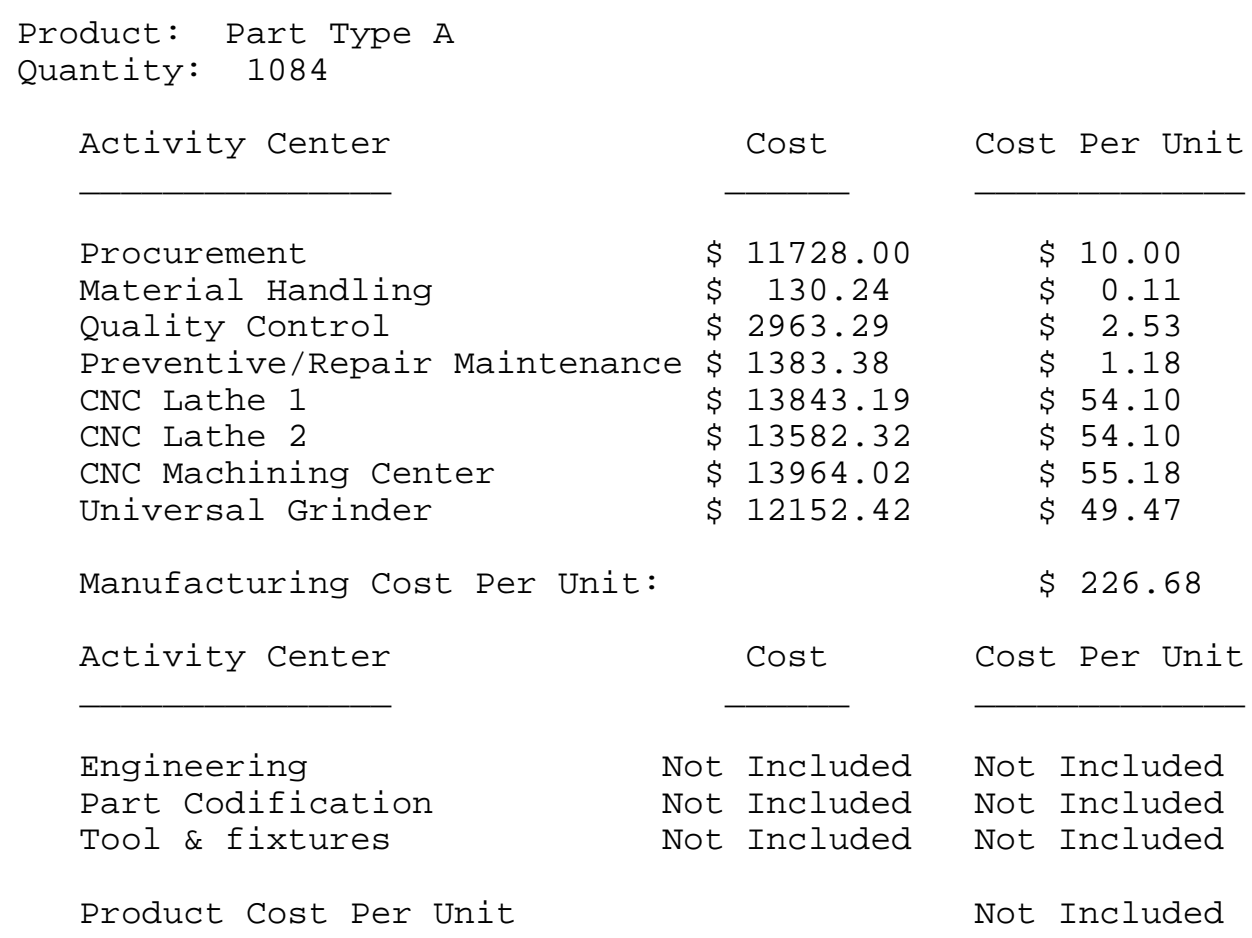

Figure 5. Example Bill of Activity. 


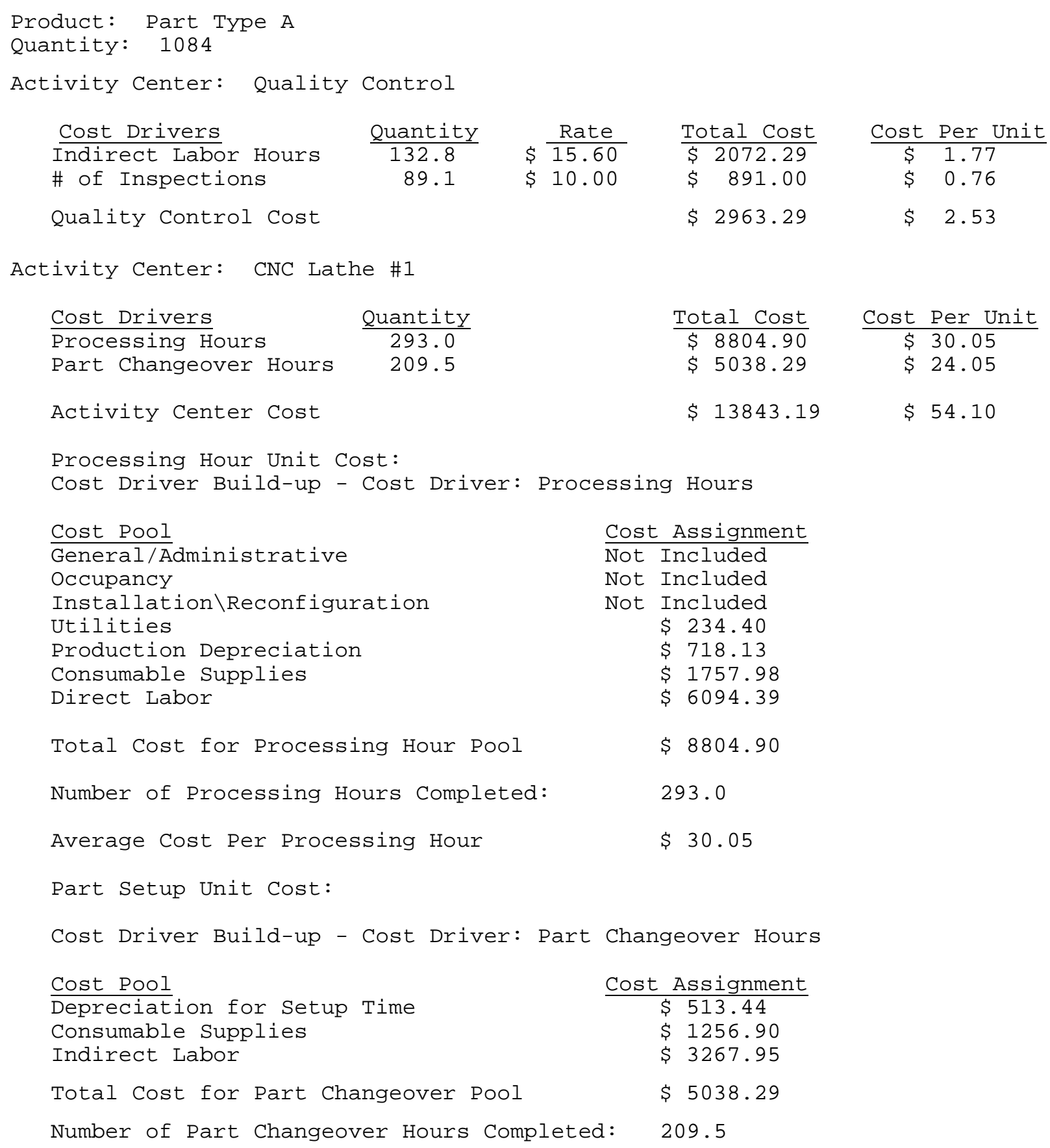

Figure 6. Example Detailed Bill of Activity. 